\title{
Studies in Eighteenth-Century
}

\author{
British Art and Aesthetics
}

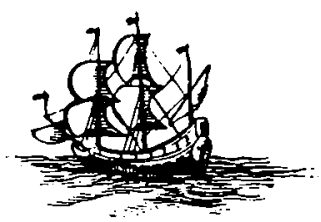

PUBLISHED UNDER THE AUSPICES OF THE

WILLIAM ANDREWS CLARK MEMORIAL LIBRARY

UNIVERSITY OF CALIFORNIA, LOS ANGELES 


\author{
Publications from the \\ CLARK LIBRARY PROFESSORSHIP, UCLA
}

1.

England in the Restoration and Early Eighteenth

Century: Essays on Culture and Society

Edited by $H$. T. Swedenberg, Jr.

2.

Illustrious Evidence

Approaches to English Literature of the

Early Seventeenth Century

Edited, with an Introduction, by Earl Miner

3.

The Compleat Plattmaker

Essays on Chart, Map, and Globe Making in England

in the Seventeenth and Eighteenth Centuries

Edited by NormanJ. W. Thrower

4.

English Literature in the Age of Disguise

Edited by Maximillian E. Novak

5.

Culture and Politics

From Puritanism to the Enlightenment

Edited by Perez Zagorin

6.

The Stage and the Page

London's "Whole Show" in the

Eighteenth-Century Theatre

Edited by Geo. Winchester Stone, Jr.

7.

England's Rise to Greatness, 1660-1763

Edited by Stephen B. Baxter

8.

The Uses of Science in the Age of Newton

Edited by John G. Burke

9.

Studies in Eighteenth-Century

British Art and Aesthetics

Edited by Ralph Cohen 


\title{
Studies in
}

\section{Eighteenth-Century \\ British Art and \\ Aesthetics}

\author{
Edited by \\ RALPH COHEN
}

Clark Library Professor, 1980-1981 
University of California Press

Berkeley and Los Angeles, California

University of California Press, Ltd. London, England

Copyright (C) 1985 by The Regents of the University of California

Library of Congress Cataloging in Publication Data Main entry under title:

Studies in eighteenth-century British art aesthetics.

(Publications from the Clark Library professorship, UCLA; 9)

1. Arts, British-Addresses, essays, lectures.

2. Arts, Modern-18th century-Great Britain-Addresses, essays, lectures. 3. Aesthetics, British-Addresses,

essays, lectures. I. Cohen, Ralph, 1917- . II. Title.

III. Series.

$\begin{array}{llll}\text { NX543.S78 } & 1985 & 7001.1 & 84-2693\end{array}$

ISBN 0-520-05258-7

Printed in the United States of America

123456789 